\title{
Calculus \\ bovis/Moschus/Olibanum/Myrrha Capsule
}

National Cancer Institute

\section{Source}

National Cancer Institute. Calculus bovis/Moschus/Olibanum/Myrrha Capsule. NCI

Thesaurus. Code C121642.

An orally available traditional Chinese medicine (TCM)-based capsule formulation

containing Calculus bovis, the dried gallstones of cattle, Moschus, also referred to as deer musk, the resin Olibanum and the resin Myrrha, with potential antineoplastic and chemopreventive activities. Although the exact mechanisms of action through which the active ing redients in the Calculus bovis/Moschus/Olibanum/Myrrha capsule elicit their effects have yet to be fully elucidated, they may, upon intake, exert their antineoplastic activity through modulation of the immune system, inhibition of tumor cell proliferation and induction of apoptosis. 